\title{
History of Psoriasis and Parapsoriasis
}

\author{
By Karl Holubar
}

\section{SUMMARY}

Parapsoriasis is not a disease entity. It is an auxiliary term introduced in 1902 to group several dermatoses with a faint similarity to psoriasis. The historical development leading to the creation of the term parapsoriasis is outlined and the history of psoriasis is briefly reviewed.

\section{Semantic and terminological considerations}

Obviously, para-psoriasis as a term has been created in analogy to psoriasis. We should remember similar neologisms in medical language, e.g. protein and para-protein; typhoid and para-typhoid, thyroid and para-thyroid, phimosis and para-phimosis, eventually, pemphigus and para-pemphigus (the latter in $1955^{1}$; this term was to be employed instead of pemphigoid but was not accepted by the dermatological world). Literally, pará is a Greek preposition, (with the genitive, dative and accusative), meaning: by the side of, next to something, alongside something. In medicine, para is used often as a prefix to another term, which designates a condition somewhat similar to the one under consideration. The same holds for psoriasis and parapsoriasis. In detail, though, it is a bit more complicated. Parapsoriasis has more than one "father", three in fact: Heinrich Auspitz (1835-1886), Paul Gerson Unna (1850-1929) and Louis Brocq (1856-1928). Auspitz, in 1881, had published a new system of skin diseases ${ }^{2}$, the seventh class of which was called epidermidoses, subdivided into hyperkeratoses, parakeratoses, keratolyses, the characteristics of which were excessive keratinization, abnormal keratinization and insufficent keratinization. When Unna, in $1890^{3}$, published his two reports on what he called parakeratosis variegata, he referred to Auspitz' system and term when coining his own. Unna's parakeratosis has to be understood in this sense even if he had some reservations; variegata is derived from variegare (post-classic latin; from varius-ago, to make of various sorts or colors). In Brocq's parlance, parapsoriasis clearly relates to psoriasis, better say, to conditions with faint similarities to psoriasis, i.e. reddish, scaly, lesions (see below) ${ }^{4}$. 
Unna had in mind a process with some anomaly of keratinization i.e. a theoretical reasoning, while Brocq referred to a clinical entity (psoriasis) in his allusion. (Unna elaborates in detail on Auspitz' system and on his own theoretical considerations which are of no relevance in this context) ${ }^{3}$.

\section{History of Psoriasis}

This question has recently been dealt with more extensively ${ }^{5}$ but the essential facts shall be reiterated. If we consider psoriasis a disease entity, Robert Willan (1757-1812) must be credited with elaborating the first lucid clinical description ${ }^{6}$. Due to his unfortunate choice of the term lepra to designate certain forms of psoriasis, a considerable semantic confusion resulted which was cleared up only decades later. As attested to by Erasmus Wilson (1809-1884), it was Ferdinand Hebra (1816-1880) who must be given credit for this clarification ${ }^{5}$. Towards the end of the last century psoriasis presented itself in the textbooks of the time ${ }^{7}$ not much differently than it is described in today's.

When we turn to psoriasis as a medical term, we may look back far into history. The term psoríasis was first employed by Galenos of Pergamon (129-200 $)^{8}$ denoting an itchy eruption of the scrotum. The substantive psóra, the verb psoriáo and the adjective hypopsoródea date back to the Corpus Hippocraticum $\left(\mathrm{see}^{5}\right)$, standing for scab (mange), to itch, and, somewhat itchy. No relation to psoriasis of our days is possible. Over the centuries, from antiquity right up to Willan, psoriasis must be conceived of as a "pot", diagnostically, into which the most different eruptions were thrown as long as they were ${ }^{1}$ on the skin, ${ }^{2}$ scaly or (de)pigmented and ${ }^{3}$ circumscribed. Lepra, vitiligo, ringworm and many more may be included. Due to the fact of visibility and not of causing symptoms, - which ever so often is the main complaint in dermatology, - a term once employed for diagnosis has faithfully been kept throughout history. Efficacious therapy was unavailable, anyway.

\section{History of Parapsoriasis}

As evidenced by the description in contemporary textbooks (in French and German) ${ }^{7}$, we may be sure that all authors concerned were familiar with the 
full clinical spectrum of this vexing disease. Unna's papers on parakeratosis variegata had just been out at this point of time (1890) ${ }^{3}$. His first patient, a 33-year old Frenchman, (referred to him by Ernest Esnier [1831-1909]), presented with a patchy, reddish, and scaly eruption on his trunk, neck and upper extremities. The second patient was a 27 -year old man, again with a scaly eruption, yellowish to reddish in color but with less circumscribed lesions and more extensive involvement of the skin of the trunk and extremities. Albert Neisser's (1855-1916) patient of $1894^{9}$, diagnosed descriptively as «lichenoides und psoriasisartiges Exanthem» already semantically related to psoriasis. Brocq's patient of $1897^{10}$, a 60 -year old lady with a 15-year eruption, presented with «des plaques disseminées [...] sur presque tout le corps; [ ...] ]leur forme générale est celle d'un cercle ou d'un ovale; [...] ]elles sont d'un rouge pâle, plutôt rosé; [...] Sur ce fond d'un rouge clair, se voient de nombreuses squames blanches». ${ }^{10}$ (p. 377). He made a diagnosis of érythrodermie pityriasique en plaques disseminées. Fritz Juliusberg (1872-?), in $1899^{11}$, referring to Neisser's patient in $1894^{9}$, to another of Joseph Jadassohn's (1863-1936), presented at the same meeting as Neisser's as dermatitis psoriasiformis nodularis ${ }^{11}$, referring also to several case presentations in France and Hungary $\left(\mathrm{see}^{11}\right)$, and an earlier report by himself, came up with the term pityriasis lichenoides chronica. Juliusberg therefore was in full knowledge of the earlier case reports (and terms), and of Brocq's paper of one year before ${ }^{10}$. He for the first time tried to synthetize the clinical data available to him and proposed a new semantic designation (i.e. pityrasis lichenoides chronica). Brocq in 1902 attempted to sum up the development by himself coining the term parapsoriasis ${ }^{4}$ (in English $1903^{12}$ ). Brocq did so by first referring back to Unna's report and term, of $1890^{3}$, and unraveled the whole story again. He carefully studied all previous reports and tried to elaborate a common denominator for classification, bearing in mind the similarities of the conditions described and the differences vis-à-vis psoriasis per se. In his paper he beautifully deals, point by point, with the German reports (A), the French reports (B), the American papers (C), the English papers (D) ${ }^{4}$ (p. 433-445) and then started an "étude synthéthique» (p. 445): He refers to dermatoses which are hallmarked by reddish, scaly lesions, with or without pruritus, slow evaluation and hardly any response to local therapy. On page $444{ }^{6}$ he then writes: «Disons tout de suite que nous avons choisi pour tout ce groupe de faits la dénomination fort discutable, mais courte et non encore utilisée, de Parapsoriasis». The publication appeared in the April issue of 1902 of the French «Annales» and this nonentity was born". 
Considering the difficulty to group together clinically widely different eruptions, this was a daring approach comparable to Brocq's other attempt a few years earlier, welding together the non-pemphigus group of bullous dermatoses and creating the dermatite polymorphe douloureuse. Another herculean task of the master that merits our admiration.

Shortly after, in $1904^{13}$, his concept was reiterated in the French handbook of dermatology co-edited by Brocq. This notwithstanding, Henry Radcliffe-Crocker (1845-1909), in 1905 ${ }^{14}$, introduced his version, describing xanthoerythrodermia perstans, Eduard Jacobi (1862-1915), in 1907, described poikilodermia vascularis atrophicans ${ }^{15}$. In 1916, Viktor Mucha (1877-1933) presented a patient with an acute exacerbation of such an eruption but did not yet offer another new term ${ }^{16}$. This is done by Rudolf Habermann (1884-?), in 1925, who writes on pityriasis lichenoides et (ac) varioliformis acuta ${ }^{17}$. With this, the pre-WWII neologisms were complete. Parapsoriasis and pityriasis lichenoides chronica as well as parakeratosis variegata were used side by side, perhaps with some national bias. When Joseph Jadassohn (1863-1936) started the edition of his monumental handbook in 1926/1927, the most comprehensive documentation of contemporary dermatological knowledge ever undertaken, Fritz Juliusberg dealt with the chapter of parapsoriasis under which he subsumed all the entities hitherto created in four decades. He wrote: «Gewisse in einzelnen Herden auftretende Erythrodermien haben unter dem Sammelbegriff der <Parapsoriasis> eine einheitliche Auffassung gefunden ${ }^{18}$ (p. 289). Thus, Brocq's term was used as an all-encompassing, if imprecise, diagnosis made up of a variety of clinical syndromes for which no better common denominator was available ${ }^{18}$.

When Achille Civatte (1877-1956), cooperator of Louis Brocq, «l'un des ouvriers de la première heure» ${ }^{19}$, commented on occasion of the semi-centennial of the establishement of the term parapsoriasis, he wrote, «il semble bien que quelques faits nouveaux, et surtout une étude plus précise de ces dermatoses, appuyée sur l'histopathologie, oblige aujourd'hui à modifier un peu la formule de Brocq ${ }^{19}$ (p. 22). No way that the non-entity should be abolished. And so it remained or another couple of decades.

Only in 1981, Clark Lambert and Mark Allen Everett attempted to review the semantic and conceptual complex and also emphasized the malignant potential of certain forms of parapsoriasis capable to progress into lymphoma ${ }^{20}$. A similarly detailed elaboration is presented by the same author (Lambert) ${ }^{21}$ in vol. 3 no. 4 of the Dermatological Clinics (October 
$1985)$ and in the third edition of Fitzpatrick's textbook ${ }^{22}$. The conclusion of all this painstaking work is that parapsoriasis is not a disease entity and it is not a collection of precursors of T-cell lymphoma. Part of the eruptions subsumed under the term of parapsoriasis, notably socalled large plaque parapsoriasis do have a malignant potential. Due to the fact that this diagnosis of large plaque parapsoriasis is made by many authors but not by all, the ambiguities not only of clinical separation of the different varieties continue. Due to the fact that clinical entities of more recent vintage, e.g. lymphomatoid papulosis, by some are considered to overlap with MuchaHabermann disease (pityriasis lichenoides chronica ac varioliformis acuta), semantic and nosologic difficulties have even increased. Recent attempts at classification of T-cell lymphomas also by determination of their surface antigens ${ }^{23,24}$ constitute the most modern armamentarium for tackling the problems of malignant potential in lymphomas and potential precursors. Discussion of these problems is not within the scope of this historical review.

Imperfect and an artifact as it is, parapsoriasis has remained the auxiliary term it was meant to be, almost ninety years ago. The fact that even with our sophisticated techniques, it is not possible to introduce yet a better term encompassing the various clinical syndromes subsumed under this diagnosis, attests to the ingenuity of Louis Brocq. One would like to speculate, that the master was fully aware of the difficulties of classification when he first conceived the idea of it, in the early years of the century when he was "in exile" from the Hôpital Saint-Louis (till 1905) ${ }^{25}$. 


\section{References}

1 Holubar, K.: Historical background, in: Management of blistering diseases (Wojnarowska, F. Briggaman, R. eds.). Chapman \& Hall, London, 1990 p. 1-12.

2 Auspitz, H.: System der Hautkrankheiten. Braumüller, Vienna, 1881, p. 121.

3 Dr. Unna, in Gemeinschaft mit Dr. Santi (Bern) und Dr. Pollitzer (New York): Über die Parakeratosen im allgemeinen und eine neue Form derselben (Parakeratosis variegata), Monatsh. prakt. Dermatol. 10: 404-412; 444-459, 1890.

4 Brocq, L.: Les Parapsoriasis, Ann. Derm. Syph. 35: 433-468, 1902 (tome III-1902).

5 Holubar, K.: Psoriasis-1001 Years Ago, Dermatologica 1989 (in press).

6 Bateman, T.: Delineations of cutaneous diseases: Exhibiting the characteristic appearances of the principal genera and species comprised in the classification of the late Dr. Willan. Longman Hurst Rees Orme and Brown, London 1817.

7 Kaposi, M.: Pathologie et traitement des maladies de la peau (transl. \& ed. by Besnier, E., Doyon, A.). Masson, Paris, 1891, 2nd revised and enlarged edition.

8 Galen, Cl.: Opera omnia; Kühn, C.G. (ed.) vol. XIX. Lipsiae, Cnobloch, 1830, p. 449.

9 Neisser: Zur Frage der lichenoiden Eruptionen, Verh. Dtsch. Derm. Ges. IV. Congr. Breslau 1894. Springer, Berlin.

10 Brocq, L.: Les érythrodermies pityriasiques en plaques disseminées, J.Practiciens 11: $577-580,1897$.

11 Juliusberg, F.: Über die Pityriasis lichenoides chronica (psoriasiform-lichenoides Exanthem), Arch. Derm. Syph. 50: 359-374, 1899.

12 Brocq, L.: Parapsoriasis, J. Cut. Diseases. 21: 315-322, 1903.

13 Audry, Ch.: Psoriasis, in: Besnier, E., Brocq, L., Jacquet, L.: La pratique dermatologique. Masson, Paris, vol.4. (1904), p. 88-148.

14 Radeliffe-Crocker, H: Xantho-erythrodermia perstans, Brit. J.Dermatol. 17: 119-134, 1905.

15 Jacobi: Fall zur Diagnose (Poikilodermia vascularis atrophicans), Verh. Dtsch. Derm. Ges. IX. Congr. Bern, 1906. Springer, Berlin, p. 321-323.

16 Mucha, V.: Über einen der Parakeratosis variegata (Unna) bzw. Pityriasis lichenoides chronica (Neisser-Juliusberg) nahestehenden eigentümlichen Fall, Arch. Derm. Syph. 123: 586-592, 1916 (Tables XXX, XXI).

17 Habermann, R.: Über die akut verlaufende, nekrotisierende Unterart der Pityriasis lichenoides (Pityiasis lichenoides et varioliformis acuta), Dermat. Zeitschr.45: 42-48, 1925.

18 Juliusberg, F.: Die psoriasiformen, pityriasiformen, exfoliativen Erythrodermien, in: J. Jadassohn, Handbuch der Haut- und Geschlechtskrankheiten. Springer, Berlin 1928, vol. VII/1 p. 289-400.

19 Civatte, A.: Le cinquantenaire du parapsoriasis, Ann. Derm. Syph. 78: 5-22, 1951.

20 Lambert, W.C., Everett, M. W.: The nosology of parapsoriasis, J. Am. Acad. Dermatol. 5: 373-395, 1981.

21 Lambert, W. C.: Premycotic eruptions, Dermatologic Clinics 3: 629-645, 1985.

22 Lambert, W. C.: Parapsoriasis, in Dermatology in general medicine (Fitzpatrick, T.B. et al. eds.). McGraw Hill, New York, 3rd ed. 1987, p. 391-1006 (chapter no. 86). 
23 Suchi, T., Lennert, K., Tu L. Y. et al.: Histopathology and immunohistochemistry of peripheral T-cell lymphomas. A proposal for classification of T-cell lymphomas, J.Clin. Pathol. 40: 995-1015, 1987.

24 Sterry, W., Korte, B., Schubert, C.: Pleomorphic T-cell lymphoma and large-cell anaplastic lymphoma of the skin, Am. J. Dermatopathol. 11: 112-123, 1989.

25 Pautrier, L. M.: Jean Louis Brocq (1856-1928), Am. J. Dermatopathol. 8: 79-82, 1986.

\section{Zusammenfassung}

\section{Geschichte der Psoriasis und Parapsoriasis}

Die Parapsoriasis ist keine Krankheitseinheit. Diese Diagnose ist ein Hilfsbegriff, der 1902 eingeführt wurde, auch auf Grund einer entfernten Ähnlichkeit mit der Psoriasis. Die geschichtliche Entwicklung dieses Terminus wird elaboriert; die Geschichte der Schuppenflechte wird kurz dargelegt.

\section{Résumé}

\section{L'histoire du psoriasis et du parapsoriasis}

Le parapsoriasis ne constitue pas une entité nosologique. Ce diagnostic est un concept auxiliaire introduit en 1902 pour grouper plusieurs dermatoses présentant une lointaine ressemblance avec le psoriasis. L'auteur retrace le développement historique de ce terme et esquisse brièvement l'histoire du psoriasis.

Prof. Dr. Karl Holubar

Institut für Geschichte der Medizin

Währinger Straße 25

A-1090 Wien/Vienna, Austria 